\title{
TAXONOMIC IMPORTANCE OF THE PALYNOLOGICAL FEATURES OF SOME MEMBERS OF FAMILY LEGUMINOSAE- CAESALPINIOIDEAE
}

\author{
Arogundade, O.O.*, Fatunmise, A.J. and Bernard, T.T. \\ Department of Botany, Obafemi Awolowo University, Ile-Ife, Nigeria. \\ *Corresponding author's e-mail: oluwabunmiarogundade@gmail.com
}

(Received: $17^{\text {th }}$ May, 2019; Accepted: $2^{\text {nd }}$ August, 2019)

\section{ABSTRACT}

\begin{abstract}
Acetolysed pollen grains of eight species in the Leguminosae- Caesalpinioideae were studied with the aim of identifying palynological characters of taxonomic importance among the taxa and determining their probable evolutionary relationships. The Acetolysis procedure and pollen type description were carried out following standard methods. The eight species include two species from genus Cassia Linn. - Cassia sieberiana DC and Cassia fistula Linn and six species from genus Senna Mill. - Senna occidentalis (Linn.) Link, Senna siamea (Lam.) Irwin and Barneby, Senna podocarpa (Guill. \& Perr.) Lock, Senna birsuta (Linn.) Irwin and Barneby, Senna obtusifolia (L.) Irwin and Barneby and Senna sophera (L.) Roxb. The pollens of all the species were shed as monads and they all had perforate sculpturing pattern on their exine. The pollen size of all the species falls into the group media $(25-50 \mu \mathrm{m})$. All the species had ovate pollen shapes except for some additional circular, elliptic and club-shaped types observed in some of the species. All the species had monocolporate and tricolpate pollen grain types. Tetracolpate, pentacolpate and hexacolpate pollen grains, which are advanced pollen types were observed only in the species of Senna while the primitive pollen types, acolpate and monocolpate, were observed more in the members of the genus Cassia, thus, the evolutionary advancement of Senna over Cassia was discussed. Other pollen types observed in some of the species were bicolpate, trilete, diporate, tricolporate, and pentacolporate. Their importance in the identification and classification of the Cassia and Senna species was also discussed.
\end{abstract}

Keywords: Pollen grains, Cassia, Senna, Aperturate, Monocolporate, Tricolpate.

\section{INTRODUCTION}

The Leguminosae family is one of the most successful flowering plants and the third largest family among the Angiosperms (LPWG, 2013) It is of much economic importance as food crops, ornamentals and weeds (Lewis et al., 2005; Yahara et al., 2013). Members of the family exhibit diverse habits and are found growing in different ecological zones of the world (Schrire et al., 2005). About 770 genera and over 19,500 species have been reported for the family (Lewis et al., 2005, 2013; LPWG, 2013). One of the best known economic importance of the family is the ability of its members to fix atmospheric nitrogen, thereby enriching the soil where they grow.

The family Leguminosae is classified into three sub-families, Caesalpinioideae DC., Mimosoideae DC., and Papilionoideae DC. (Lewis et al., 2005; Cullen et al., 2011). However, the classification was observed to be insufficient as a result of the diverse floral pattern in the family and especially the paraphyletic nature of sub-family
Caesalpinioideae (Doyle et al., 1997; Bruneau et al., 2008; LPWG, 2013). Based on this, the earlier classification into the three sub-families was pointed out as obsolete and a revision of the family was carried out using morphological and molecular data. This resulted into further division of the family into six subfamilies, Cercidoideae Detarioideae, Duparquetioideae, Dialioideae, recircumscribed Caesalpinioideae and Papilionoideae (LPWG, 2017).

Subfamily Caesalpinioideae has been reported to contain about 148 genera and ca. 4400 species which include trees, shrubs, lianas and suffruticose with some of its members armed with prickles or spines. The detailed morphological description of this subfamily is as presented in the writings of LPWG (2017). The subfamily has also been recognised as paraphyletic in which there is a need to clarify some taxonomic identity problems among its members (LPWG, 2017). The species worked on in this study are members of genera Cassia Linn. and Senna Mill. which both belong to the subfamily 
Caesalpinioideae.

Genus Cassia L. senso lato was raised to a subtribe level as subtribe Cassiinae from which three distinct genera were named: Chamaecrista Moench., Senna P. Mill. and Cassia L. senso stricto (Irwin and Barneby, 1981 and 1982). This subdivision of Cassia L. senso lato into three distinct genera has been ascertained by different authors around the world who employed data from various fields of evidence. Such authors include Marazzi et al. (2006); Acharya, et al. (2011) and Abdalla, et al. (2016).

Palynological evidences have proven useful at all taxonomic levels because the structure of the pollen wall which is usually being employed in the study is not affected by environmental factors Nnamani and Onu (2014). Palynological characters have therefore been variously employed in the taxonomy of species of plants, forensic sciences, crime site detection, archaeology, paleoecology, delimitation of closely related or sympatric species, valuable in phylogenetic inferences (Nyananyo, 1992; Akinwusi and Illoh, 1996; Edeoga et al., 1998; Adedeji, 2005; Arogundade and Adedeji, 2009; Simpson, 2010, Arogundade and Lawal, 2018). According to Acharya et al. (2011), there are still a lot of taxonomic work to be done at the genera and specific levels of the subfamily Caesalpinioideae. This work therefore intends to use palynological evidence as a tool in the ongoing review of the paraphyletic subfamily Caesalpinioideae by identifying the different types of pollen grains and pollen characters of taxonomic importance among some species of Cassia and Senna.

\section{MATERIALS AND METHODS}

The acetolytic method described by Erdtman (1960) and as modified by Arogundade and Lawal (2018) was employed in acetolysing the pollen grains collected from fresh anthers of eight members of the Caesalpinioideae. The members include two species from genus Cassia Linn. Cassia sieberiana DC and Cassia fistula Linn. and six species from genus Senna Mill. - Senna occidentalis (Linn.) Link, Senna siamea (Lam.) Irwin and Barneby, Senna podocarpa (Guill. \&
Perr.) Lock, Senna birsuta (Linn.) Irwin and Barneby, Senna obtusifolia (L.) Irwin and Barneby and Senna sophera (L.) Roxb. The pollens were collected at different locations within Obafemi Awolowo University, Ile-Ife campus, Osun State $7.5165{ }^{\circ} \mathrm{N}, 4.5286^{\circ} \mathrm{E}$ and Saki, Oyo State, $8.6726^{\circ} \mathrm{N}, 3.3943^{\circ} \mathrm{E}$, all in South Western part of Nigeria. They were stored in absolute ethanol prior to Acetolysis.

The acetolytic method includes series of centrifugation at $350 \mathrm{rpm}$ for 20 minutes at each stage. The first stage involved the maceration of anthers in absolute ethanol. The supernatant was poured off and glacial acetic acid added for the next centrifugation. This solvent too was poured off after the centrifugation and acetolysis mixture (sulphuric acid and acetic anhydride in ratio 1:6) was added. The tubes containing these mixtures were then placed in a water bath and heated from a temperature of $70{ }^{\circ} \mathrm{C}$ to boiling point with intermittent stirring. Centrifugation was done again and the acetolysis mixture was poured off. Glacial acetic acid was added next, centrifuged and it was poured off. Finally, distilled water was added to the sediment and was followed by another centrifugation. The water was later decanted and the acetolysed pollen grains were mounted in dilute glycerine solution.

The acetolysed pollen grains were observed under Olympus XSZ-107BN binocular biological microscope (Zenith Laboratories, California). For each of the species, 150 pollens were chosen at random and studied. Attributes of the pollens which include the pollen shape, positions of the colpi and pores and pollen types based on the number of colpi and pores were described following the guidelines provided by Moore and Webb (1978) and Putt et al. (2007). Measurements of pollen diameter, depth of colpi, diameter of pore, distance between colpi and pollen wall thickness were taken with the aid of an ocular micrometer inserted into the eyepiece of the microscope. The various ocular readings were then converted into micrometer $(\mu \mathrm{m})$ by multiplying each reading with the ocular constant which corresponds to the ocular magnification under which they were taken. The photomicrographs of the pollens were taken using an AmScope camera attached to the 
microscope.

The data (quantitative and qualitative) generated from this study were subjected to univariate and multivariate statistical analysis. The mean values of each of the quantitative characters were calculated with the standard error. The data were coded and subjected to Single Linkage Cluster Analysis (SLCA) and Principal Components Analysis (PCA) using Paleontological Statistics Software Package (PAST).

\section{RESULTS}

The pollen of all the species studied were shed as monads and the sculpturing pattern on their outer wall, the exine, is perforate sculpturing.

\section{Shape of Pollens}

Four types of pollen shape were encountered in the species of Cassia and Senna studied (Figures 1 and 2; Table 1). They are ovate, circular, elliptic and club-shaped pollens. Ovate shape was observed as the main pollen shape in all the species. Elliptic pollen shape was observed in all the species as well but not in $S$. podocarpa. The frequency of the elliptic pollen shape was not as high as that of the ovate shape in the species where it was observed. Circular pollen shape, though sparsely encountered too, was observed in all the species except in $C$. sieberiana where only the ovate and elliptic pollen shapes were noted. The fourth pollen shape which is club-shape was observed only in C. fistula and not in any of the other species in this study.

\section{Position of Pores and Colpi}

Pores were sparsely encountered among the species studied. When present they were observed in the association of one or two colpi at equatorial region and they are basically one, that is, the pollens with pores are monocolporate. The only exceptions to this were observed in C. fistula where some of its pollens were observed as having two pores, Diporate, in the equatorial region and in $S$. podocarpa where tetraporate pollen grains, with four pores were observed in the polar region. The colpi observed in the species ranges from one to six and they are situated at both the polar and equatorial regions of the pollens (Figures 1 and 2; Table 1).

\section{Pollen Types}

The types of pollens observed among the species based on the number of colpi and pores on them are Acolpate (inaperturate), Monocolpate, Monocolporate, Bicolpate, Diporate, Tricolpate, Tricolporate, Trilete, Tetracolpate, Tetraporate, Pentacolpate, Pentacolporate and Hexacolpate.

All the species in this study had monocolporate and tricolpate pollen types. Pollens with no colpi at all, Acolpate types, were encountered in the two species of Cassia studied and $S$. sophera. Monocolpate pollen grain type was observed in $S$. occidentalis, S. podocarpa, S. sophera and C. fistula. Bicolpate types were observed in $S$. occidentalis, S. siamea, S. obtusifolia, S. hirsuta, $S$. sophera, C. sieberiana and C. fistula. Diporate pollen types with two pores were observed only in C. fistula while Tetraporate pollen grain types, pollens with four pores were observed only in $S$. podocarpa. Tricolporate types were observed in $S$. occidentalis, S. siamea, S. obtusifolia, S. sophera and C. sieberiana. Trilete pollen type was observed in all the Senna species except in $S$. obtusifolia and the two Cassia species. Tetracolpate pollens were encountered in $S$. obtusifolia and S. hirsuta. Pentacolpate pollens were encountered in $S$. occidentalis and $S$. sophera. Pentacolporate pollen types were observed only in S. obtusifolia. Hexacolpate pollen types were observed in S. occidentalis, S. siamea and $S$. sophera (Table 1; Figures 1 and 2).

Table 2 shows the mean values and the standard errors of the quantitative data measured on the pollens. Figure 3 shows the dendrogram of the Single Linkage Cluster Analysis which divided the species into two groups, in the first clustering, according to their genera. In the second grouping, S. podocarpa was distinctly separated from the other members of the genus Senna. Furthermore, S. obtusifolia and S. birsuta were clustered together and separated from $S$. siamea, $S$. sophera and $S$. occidentalis with $S$. sophera and $S$. occidentalis being grouped together at a higher similarity level.

The result of the Principal Components Analysis corroborates the result of the Single Linkage 
Cluster Analysis (SCLA) of the Cassia and Senna species. The first five components of ordination were responsible for $93.87 \%$ of the total variation observed among the species (Table 3). The graph of the Principal Components Analysis of the species based on components 1 and 2 is as shown in figure 4 while that of components 1 and 3 is as shown in figure 5 .

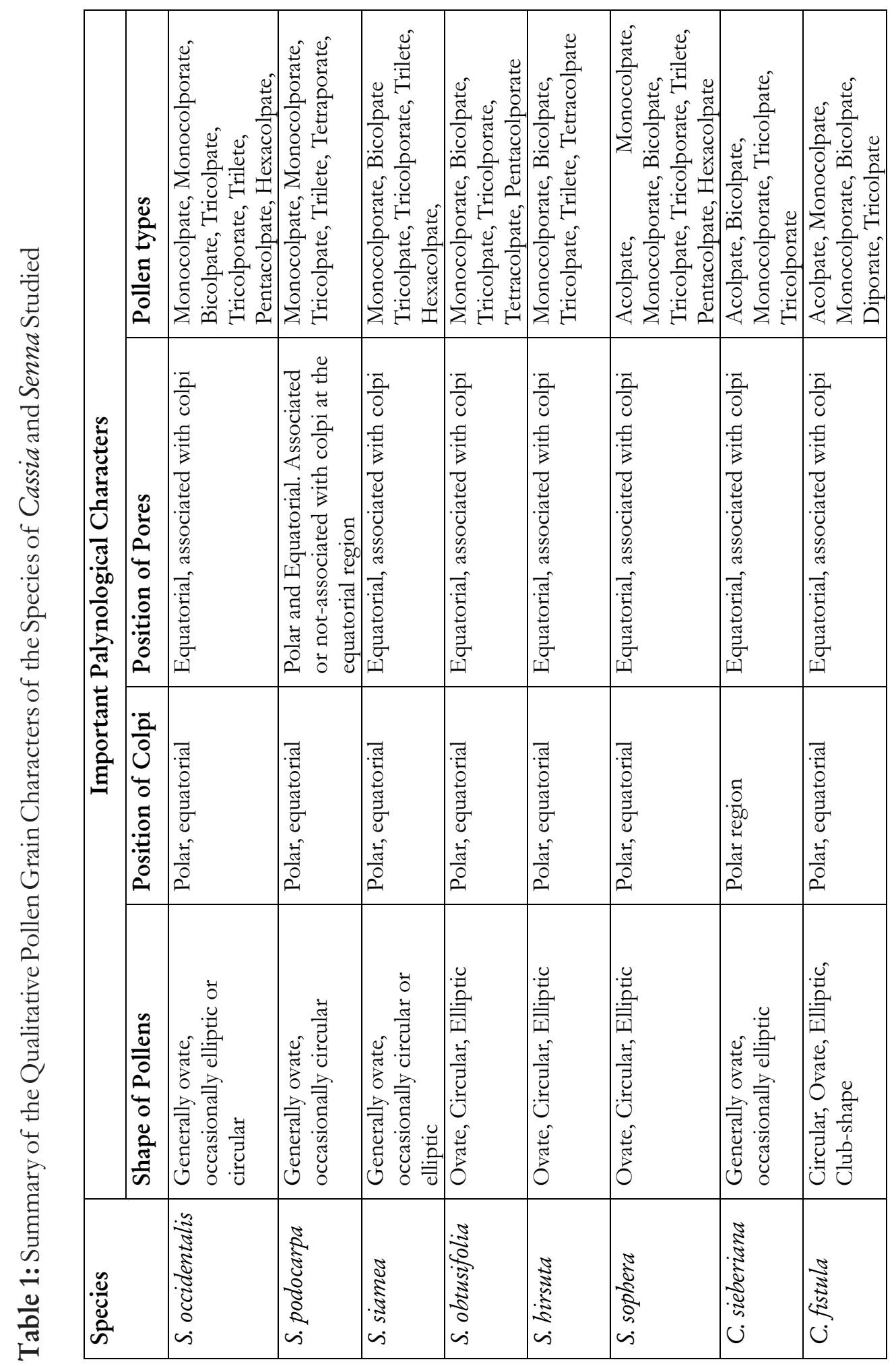


Table 2: Summary of the Quantitative Pollen Grain Characters of the Species of Cassia and Senna Studied

\begin{tabular}{|l|l|l|l|l|l|}
\hline \multirow{2}{*}{\begin{tabular}{l} 
Species \\
\cline { 2 - 6 }
\end{tabular}} & $\begin{array}{l}\text { Pollen } \\
\text { Diameter }(\mu \mathrm{m})\end{array}$ & $\begin{array}{l}\text { Colpi depth } \\
(\mu \mathrm{m})\end{array}$ & $\begin{array}{l}\text { Pore Diameter } \\
(\mu \mathrm{m})\end{array}$ & $\begin{array}{l}\text { Pollen Wall } \\
\text { Thickness }(\mu \mathrm{m})\end{array}$ & $\begin{array}{l}\text { Distance } \\
\text { between Colpi } \\
(\mu \mathrm{m})\end{array}$ \\
\hline S. sophera & $32.88 \pm 0.33$ & $18.24 \pm 0.39$ & $0.27 \pm 0.10$ & $3.39 \pm 0.01$ & $21.26 \pm 0.42$ \\
\hline S. obtusifolia & $35.84 \pm 0.23$ & $21.37 \pm 0.49$ & $5.44 \pm 0.17$ & $2.71 \pm 0.05$ & $21.19 \pm 0.49$ \\
\hline S. hirsuta & $33.70 \pm 0.20$ & $18.85 \pm 0.50$ & $4.49 \pm 0.14$ & $2.64 \pm 0.04$ & $23.33 \pm 0.32$ \\
\hline S. siamea & $34.73 \pm 0.19$ & $13.18 \pm 0.39$ & $7.18 \pm 0.20$ & $5.00 \pm 0.05$ & $29.42 \pm 0.36$ \\
\hline S. occidentalis & $32.25 \pm 0.35$ & $10.85 \pm 0.48$ & $6.79 \pm 0.22$ & $4.33 \pm 0.07$ & $28.42 \pm 0.32$ \\
\hline S. podocarpa & $31.95 \pm 0.33$ & $8.18 \pm 0.25$ & $8.35 \pm 0.25$ & $5.19 \pm 0.06$ & $26.07 \pm 0.35$ \\
\hline C. fistula & $26.85 \pm 0.29$ & $14.20 \pm 0.61$ & $3.35 \pm 0.13$ & $2.58 \pm 0.03$ & $16.45 \pm 0.39$ \\
\hline C. sieberiana & $25.02 \pm 0.26$ & $10.78 \pm 0.30$ & $4.53 \pm 0.11$ & $4.01 \pm 0.06$ & $19.98 \pm 0.32$ \\
\hline
\end{tabular}

NB: values are means \pm Standard Error, $\mathrm{n}=150$
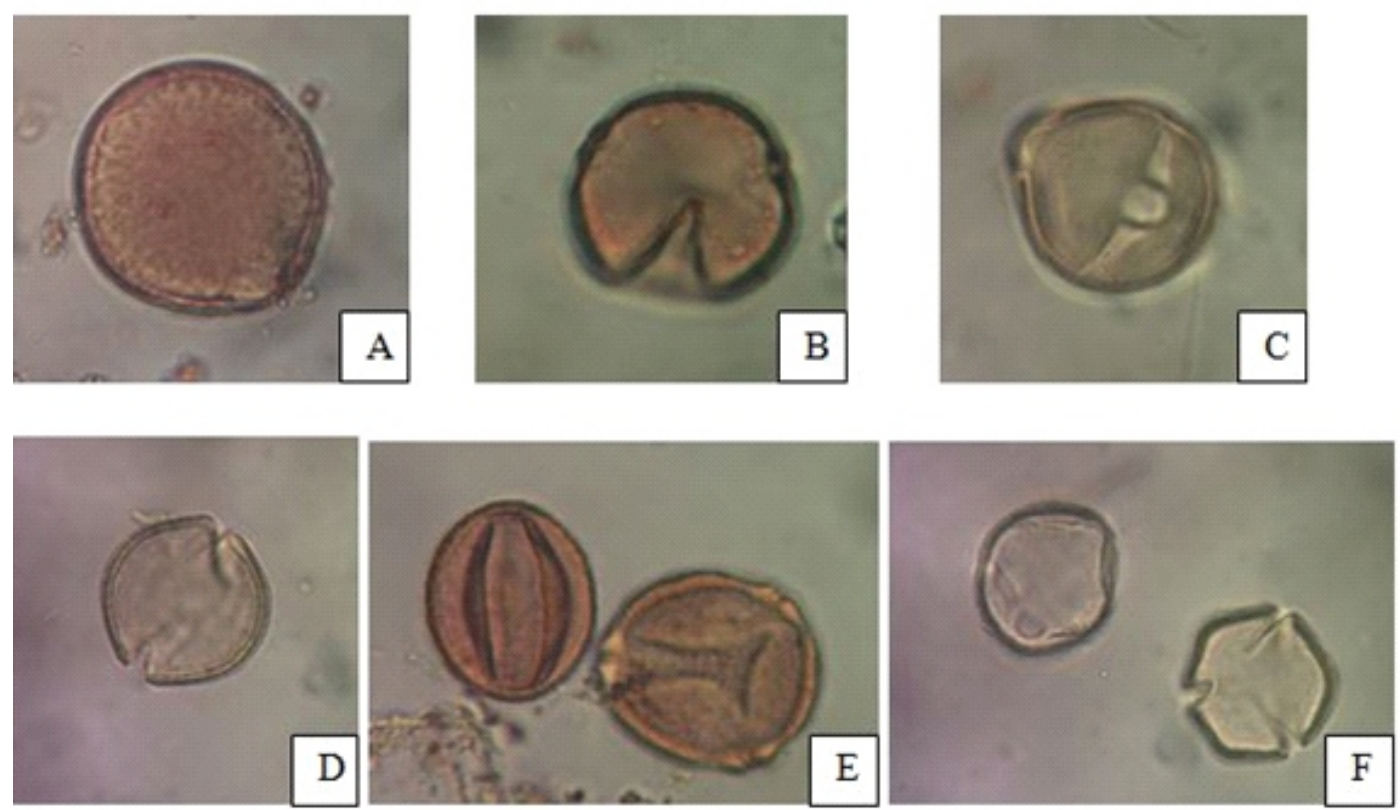

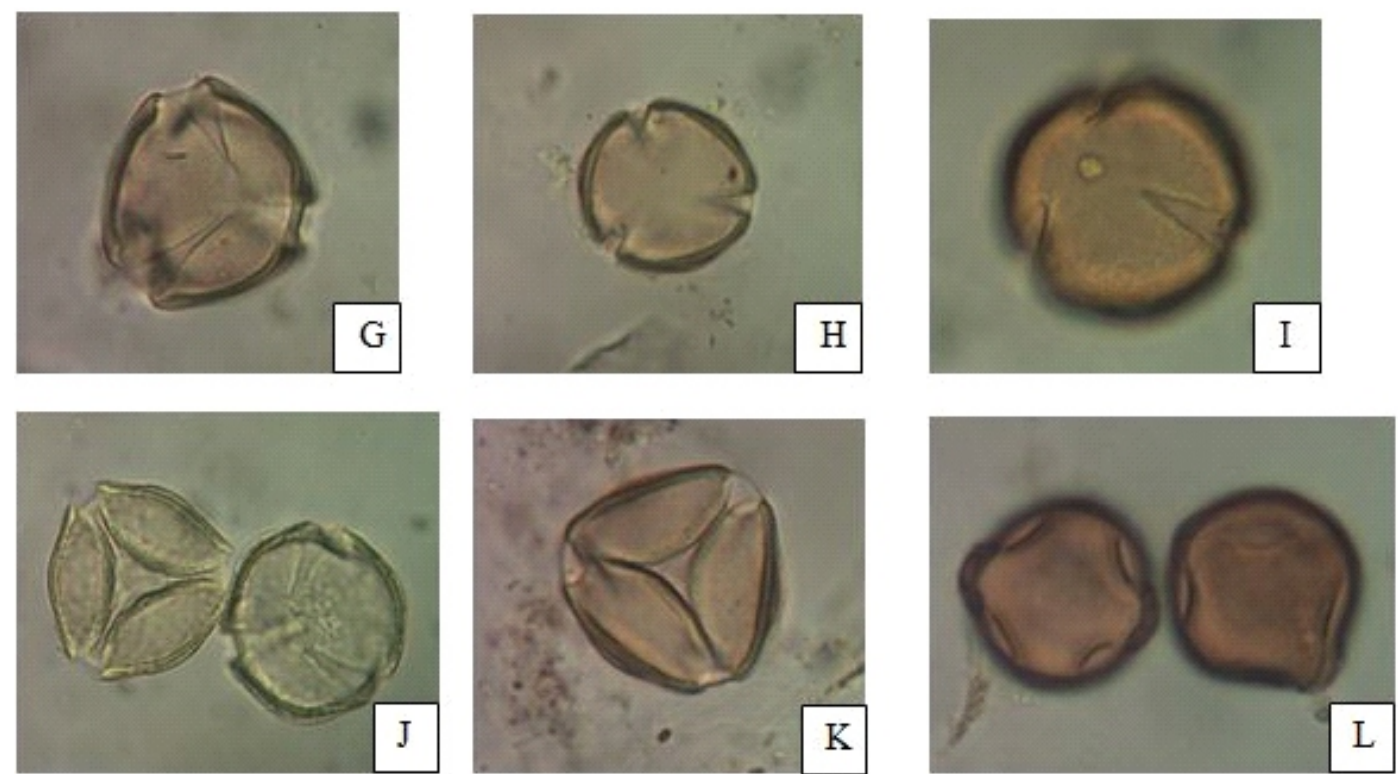

Figure 1: Pollen Grain Types in Species of Cassia and Senna Studied

A-Acolpate, B- Monocolpate, C- Monocolporate, D- Bicolpate, E- Bicolpate and Monocolpate, FMonocolporate and Tricolpate, G and H- Tricolpate, I- Tricolporate, J- Trilete and Tricolpate, KTrilete, L- Tetraporate. (Magnification x 400)
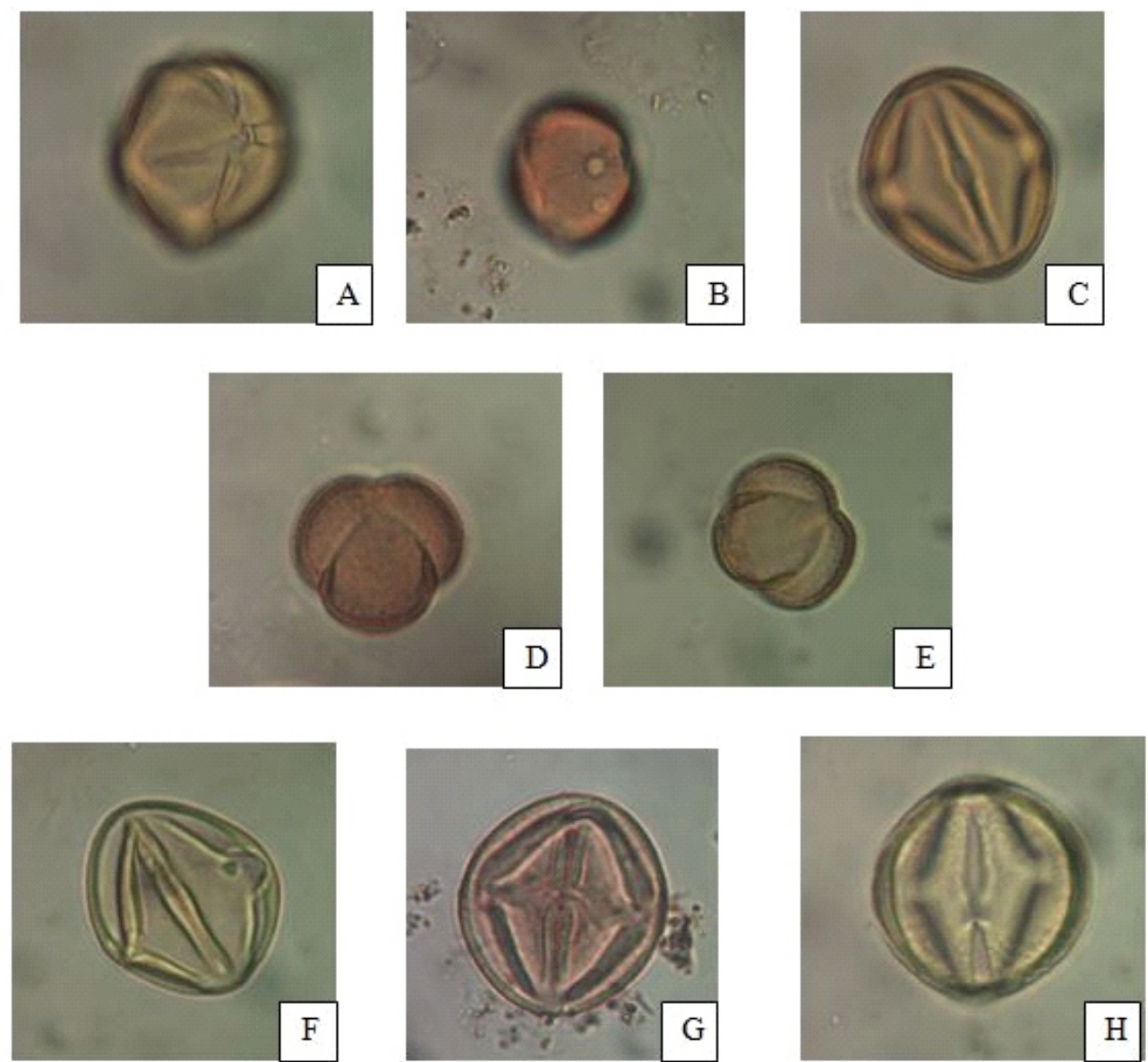

Figure 2: Pollen grain Types in Species of Cassia and Senna Studied

A- Tetracolpate, B- Diporate, C- Pentacolporate, D and E- Club-shaped (as found in C. -fistula), FPentacolpate, G and H- Hexacolpate. (Magnification x400) 


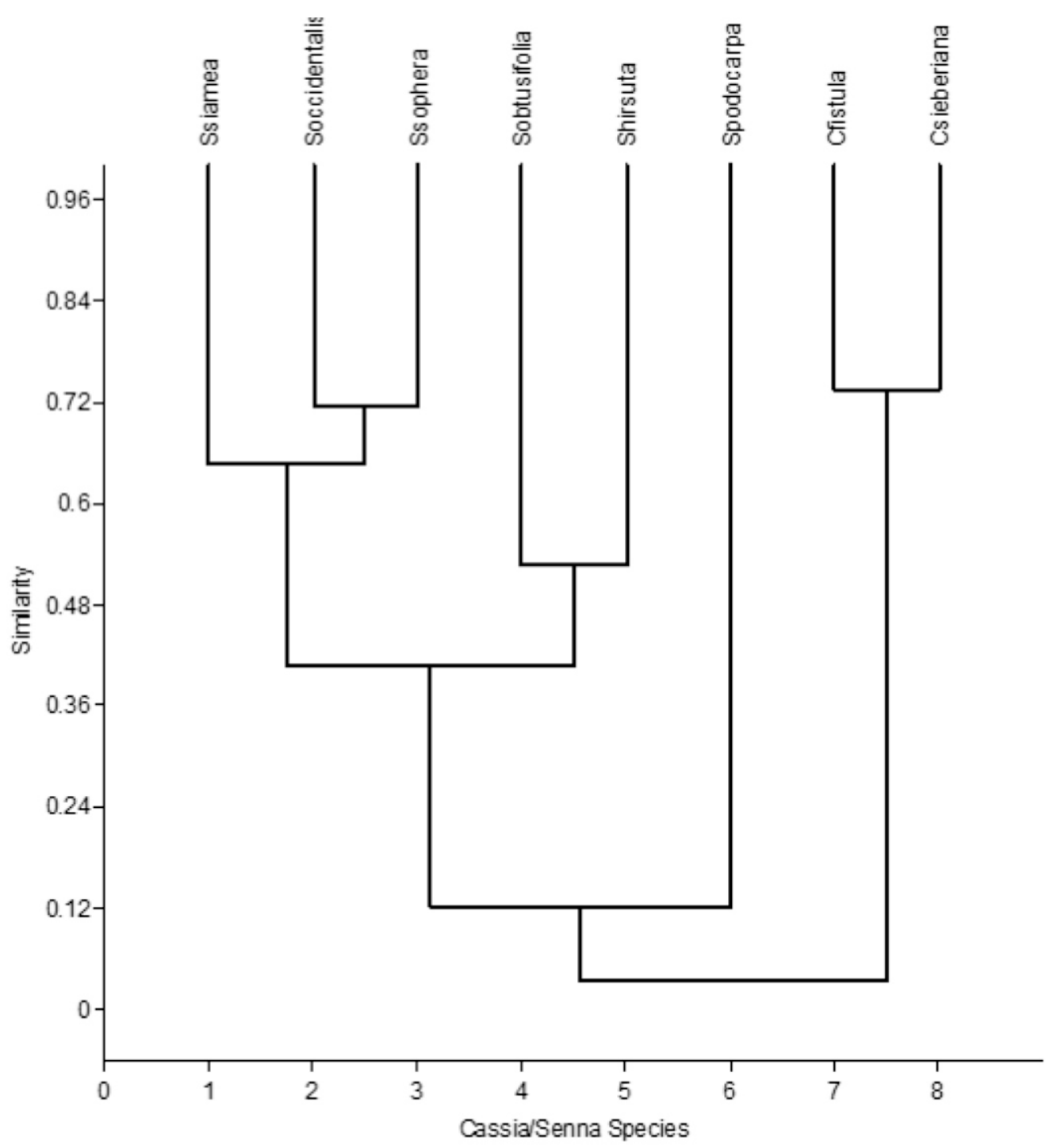

Figure 3: Dendrogram of Cassia and Senna Species Based on their Qualitative and Quantitative Pollen Characters

\section{DISCUSSION}

The members of the genera Cassia and Senna involved in this study had some pollen characters in common which affirms their sub-familial classification and close relationship as reported by Marazzi et al. (2006). All the species studied had aperturate pollen grains with either pores or colpi or both in diverse forms. Another important factor worthy of note is that all the pollens are dispersed as monads, that is, as single or individual units and the only sculpturing pattern observed on the exine of all the species is perforate.

However, a few pollen characters can still be employed in their delimitation both at the generic and specific levels. A character of interest in this study is the shape of the pollens. Ovate shaped pollen grains were observed in all the species studied, yet other types of shapes encountered in some of the species can be employed in their delimitation. Elliptic pollen shape was observed in all the species both from the polar and equatorial views but not in $S$. podocarpa. In the same vein, pollen grains with circular shapes were observed in all the species except C. sieberiana. Another unique pollen shape described as club-shaped clearly demarcates $C$. fistula from C. sieberiana and the members of genus Senna in this study. Pollen shapes have been found useful in the delimitation of groups of plants (Moore and Web, 1978; Arogundade and Adedeji, 2009).

The pollen apertures (pores and colpi) observed in 
this study also provided a good classification character among the species. Pores were not so commonly observed. The few ones encountered are circular in shape and were mostly found in association with colpi which are fissure-like openings. Varying number of colpi observed in the species offers a good classification character which is of high taxonomic significance. Nnamani and Onu (2014) reported only tricolporate pollens in the species of Senna studied. In this study, tricolporate pollens were observed in five of the species which cut across the two genera where additional pollen types were also observed. The only pollen types recorded to be common to all the species studied are monocolporate and tricolpate pollens.

Pollens with higher number of colpi were also reported in this study. The presence of higher number of colpi in any group of plants has been attributed to recent evolutionary advancement in such group of plants (Walker, 1976; Adedeji, 2005; Adedeji and Akinniyi, 2015; Arogundade and Lawal, 2018). Based on this assertion, the advancement of Senna over Cassia is established and this is as a result of the presence of more advanced pollen types- tetracolpate, pentacolpate and hexacolpate pollens, observed in the members of genus Senna and not in any of the members of Cassia. The primitive pollens types - acolpate and monocolpate pollen types observed in the species of Cassia also confirms the evolutionary advancement of Senna over Cassia. The presence of these primitive pollen grain types can thus be employed in the separation of the members of the genus Cassia from the members of the genus Senna. The uniqueness of diporate pollen types to C. fistula, tetraporate to $S$. podocarpa and pentacolporate types to $S$. obtusifolia provided a good basis for the identification of the species.

Polyploidization, which implies the presence of more than two chromosome sets per somatic cell, has been reported in the genus Senna (De Resende et al., 2013; Cordeiro and Leonardo, 2018). This condition has also been ascertained to cause increase of cell size in plants where it occurs, pollen grains inclusive (Marinho, et al., 2013). The pollen diameter of the Senna species in this study is relatively higher than that of the members of the genus Cassia and this also supports the advancement of Senna over Cassia (Adedeji, 2005). Pollen grain sizes have been classified into various groups (Erdtman, 1952) and the classification has been adopted by many authors (Akinwusi and Illoh, 1996; Adedeji, 2005; Arogundade and Lawal, 2018). Based on this classification, the pollen size of all the species of Cassia and Senna in this study falls to the group media, with dimension between $25 \mu \mathrm{m}$ and $50 \mu \mathrm{m}$.

The grouping of the species on the dendrogram resulting from the SCLA is in consonant with their respective genera, that is, members of genus Cassia were clearly separated from members of genus Senna in the first main grouping. The separation of $S$. podocarpa from the other Senna species in the second grouping was most likely due to the presence of tetraporate pollens in the species as this is the only species where tetraporate pollens were encountered. S. podocarpa is also the only species where bicolpate pollen grains were not observed. The closeness of S. obtusifolia and S. hirsuta was established in the third grouping and this is most likely due to the presence of tetracolpate pollen grains observed only in the two species. The fourth stage of grouping revealed $S$. occidentalis and $S$. sophera as close relatives at a higher similarity level which is due to the presence of pentacolpate and hexacolpate pollen types in the two. This similarity is not in consonant with the findings of Soladoye et al. (2010) who reported a distant relationship between $S$. occidentalis and $S$. sophera while conducting morphometric studies on some Senna species. There is therefore the need to carry out more research work especially on the members of genus Senna so as to clear any confusion that may arise as regards their relationships.

The outcome of the Principal Components Analysis shed more light on the identification and classification of the Cassia and Senna species. On the first component axis, the pollen diameter, pore diameter, distance between any two colpi, acolpate, bicolpate, diporate and trilete pollen grains are responsible for the separation. On the second axis component, the length of colpi, tetracolpate and pentacolpate pollen grain types 
are responsible for the variation while component three recorded the pentacolpate pollen grain type as the character responsible for the variation observed. All these characters had high component loading and are helpful in the identification of the species.

\section{REFERENCES}

Abdalla, W. E., Guma'a, A.G.N., El Ghazali, G.E.B. and Khalid, H.E. 2016. An Updated Species Check-list for the Genus Cassia L. sensu lato in the Sudan. Journal of Natural Resources and Environmental Studies, 4(2): 1-12.

Acharya, L., Mukherjee, A.K. and Panda, P.C. 2011. Separation of the genera in the subtribe Cassiinae (Leguminosae: Caesalpinioidae) using molecular markers. Acta Botanica Brasilica, 25(1): 223-233.

Adedeji, O. 2005. Pollen morphology of the three species of the genus Emilia Cass. (Asteraceae) from Nigeria. Thaiszia Journal of Botany, 15:1-9.

Adedeji, O. and Akinniyi, T.A. 2015. Pollen Morphology of Some Species in the Family Solanaceae. Journal of Advanced Laboratory Research in Biology, 6(4): 125-129.

Akinwusi, O. and Illoh, H.C. 1996. Pollen grain morphology of some species of Hibiscus Linn. Nigerian Journal of Botany, 9: 9 14.

Arogundade, O.O. and Adedeji, O. 2009. Pollen grain morphology of three species and a variety of Ocimum Linn. (Lamiaceae) in Southwestern Nigeria. Journal of Science and Technology, 29(3):1-7.

Arogundade, O.O. and Lawal, H.O. 2018. Palynological Studies of Three Taxa and One F1 Hybrid in the Genus Talinum Adans. Notulae Scientia Biologicae, 10(2):175-181.

Edeoga, R.O., Ugbo, R.N. and Osawe, P.I. 1998. Palynomorphology of species of Commelina L. and Senna Toum. Ex. Mill. from Nigeria. New Botanist, 25:1-10.

Bruneau, A., Mercure, M., Lewis, G.P and Herendeen, P.S. 2008. Phylogenetic patterns and diversification in the caesalpinioid legumes. Botany, 86: 697-718.

Cullen, J., Knees, S.G. and Cubey, H.S. (eds.). 2011. The European Garden Flora, Angiospermae-Dicotyledons: Resedaceae to Cyrillaceae. Vol. 3, 2nd ed. Cambridge: Cambridge University Press.

Cordeiro, J.M.P. and Leonardo P.F. 2018. Intraand interspecifi c karyotypic variations of the genus Senna Mill. (Fabaceae, Caesalpinioideae). Acta Botanica Brasilica, 32(1):128-134.

De Resende, K.F.M., Davide, L.C. and Torres, G.A. 2013. Chromosome number and meiosis in populations of Senna species (Caesalpinioideae - Fabaceae) from Southeast Brazil. Caryologia, 66:1, 1-5..

Doyle, J.J., Doyle, J.L., Ballenger, J.A., Dickson, E.E., Kajita, T. and Ohashi, H. 1997. A phylogeny of the chloroplast gene $r b c L$ in the Leguminosae: Taxonomic correlations and insights into the evolution of nodulation. American Journal of Botany 84: 541-554.

Erdtman, G. 1952. Pollen morphology and Plant taxonomy of Angiosperms. Almqvist and Wiksell, Stockholm, p. 539.

Erdtman, G. 1960. The Acetolysis method in a revised description. Svensk Botanisk Tidskrift, Lund, 54(4): 561-564.

Irwin, H.S. and Barneby, R.C. 1981. Cassieae. In: Polhill, R.M. \& Raven, P.H. (eds.), Advances in legume systematics, part 1. Richmond, U.K.: Royal Botanic Gardens, Kew, p. 97-106.

Irwin, H.S. and Barneby, R.C. 1982. "The American Cassiinae - A Synoptical Revision of Leguminosae tribe Cassieae subtribe Cassiinae in the New World", Mem. New York Bot. Gard., 35:1-918.

Lewis, G., Schrire B., Mackinder, B. \& Lock, M. (eds.) 2005. Legumes of the World. Richmond, U.K.: Royal Botanic Gardens, Kew.

Lewis, G.P., Schrire, B.D., Mackinder, B.A., Rico, L. and Clark, R. 2013. A 2013 linear sequence of legume genera set in a phylogenetic context: A tool for collections management and taxon 
sampling. S. African Journal of Botany, 89: 76-84.

LPWG, The Legume Phylogeny Working Group 2013. Legume phylogeny and classification in the 21st century: Progress, prospects and lessons for other speciesrich clades. Taxon, 62: 217-248.

LPWG, The Legume Phylogeny Working Group. 2017. A new subfamily classification of the Leguminosae based on a taxonomically comprehensive phylogeny. Taxon, 66 (1): 44-

Marazzi, B., Endress, P.K., De Queiroz, L.P. and Conti, E. 2006. Phylogenetic relationships within Senna (Leguminosae, Cassiinae) based on three chloroplast DNA regions: Patterns in the evolution of floral symmetry and extrafloral nectaries. American Journal of Botany, 93(2): 288-303.

Marinho, R.C., Mendes-Rodrigues, C. Bonetti, A.M. and Oliveira, P.E. 2013. Pollen and stomata morphometrics and polyploidy in Eriotheca (Malvaceae-Bombacoideae). Plant Biol(Stuttg), 16(2): 508-511.

Moore, P.D. and Webb, J.A. 1978. An Illus-trated Guide to Pollen Analysis. Hodder and Stoughton, London. p. 133

Nnamani, C. V. and Onu, E. 2014. Taxonomic Values of Pollen Features in Senna Genus (Fabaceae) from South- Eastern Nigeria. Journal of Pharmacy and Biological Sciences (IOSR-JPBS), 9(6): 54-59.

Nyananyo, B.L. 1992. Pollen morphology in the Portulacaceae (Centrospermae). Folia
Geobotanical Et Phytotaxonomica, 27(4): 387-400.

Punt, W., Hoen, P. P., Blackmore, S., Nilsson, S. and Le Thomas, A. 2007. Glossary of pollen and spores terminology. Review of Palaeobotany and Palynology, 143(1\&2):1-81.

Schrire, B.D., Lavin, M. and Lewis, G.P. 2005. Global distribution patterns of the Leguminosae: Insights from recent phylogenies. Biologiske Skrifter, 55: 375-422.

Simpson, M.G. 2010. Plant Systematics. Second edition. Academic Press, Amsterdam.

Soladoye, M.O., Onakoya, M.A., Chukwuma, E.C. and Sonibare, M.A. 2010. Morphometric study of the genus Senna Mill. in Southwestern Nigeria. African Journal of Plant Science, 4 (3): 44-52.

Walker, I.W. 1976. Evolution of exine structure in the pollen of primitive angiosperms. American Journal of Botany, 61: 891-902.

Yahara, T., Javadi, F., Onoda, Y., Queiroz, L.P., Faith, D., Prado, D.E., Akasaka, M., Kadoya, T., Ishihama, F., Davies, S., Slik, J.W.F., Yi, T., Ma, K., Bin, C., Darnaedi, D., Pennington, R.T., Tuda, M., Shimada, M., Ito, M., Egan, A.N., Buerki, S., Raes, N., Kajita, T., Vatanparast, M., Mimura, M., Tachida, H., Iwasa, Y., Smith, G.F., Victor, J.E. and Nkonki, T. 2013. Global legume diversity assessment: Concepts, key indicators, and strategies. Taxon, 62: 249-266. 